\title{
PRADINIŲ KLASIŲ MOKINIŲ MITYBOS YPATUMŲ POKYČIAI. PALYGINAMASIS 2010 IR 2014 METŲ TYRIMAS
}

\author{
Žymantas Žandaras, Rimantas Stukas \\ Vilniaus universiteto Medicinos fakulteto Visuomenès sveikatos institutas
}

Raktažodžiai: pradinių klasių mokiniai, mityba, mitybos pokyčiai.

\begin{abstract}
Santrauka
Tyrimo medžiaga ir metodai. 2010 metais dviejose Vilniaus miesto pradinèse mokyklose anoniminès anketinès apklausos būdu apklausti 460 1-4 klasių mokinių tèvai. 2014 metais tose pačiose mokyklose analogiškai apklausti 346 tèvai. Duomenys analizuoti SPSS 22.0 programa. Kokybinių duomenu analizei naudotas Pearson'o chi kvadratas $\left(\chi^{2}\right)$. Duomenų skirtumas laikytas statistiškai reikšmingu, kai $\mathrm{p} \leq 0,05$.

Rezultatai. 2010 metais sveikos mitybos rekomendacijų laikèsi 73,3\% pradinukų tėvų, 2014 metais - 84,8\%, atitinkamai kasdien pusryčiaudavo $65,7 \%$ ir $73,7 \%$ vaikų, prieš miegą valgantys vaikai 2010 metais sudare $55,2 \%$, o 2014 metais $-45,7 \%$. 3 ir daugiau kartų per dieną daržoves 2010 metais valge $12,2 \%$ respondentų vaikų, 2014 metais $-11,9 \%$, atitinkamai vaisius $22,9 \%$ ir $25,0 \%$, duoną ir grūdinius produktus $-28,5 \%$ ir $24,3 \%$. Maisto papildus 2010 metais vartojo 44,4\% pradinių klasių mokinių, 2014 metais $-52,6 \%$.

Išvados. Padaugejo besilaikančių sveikos mitybos rekomendacijų tèvų, kasdien pusryčiaujančių, taip pat vartojančių maisto papildus vaikų. Reikšmingai sumažejo prieš miegą valgančių vaikų.
\end{abstract}

\section{İvadas}

Vaikysteje ir paauglysteje formuojasi vaiko elgsenos ir gyvensenos pagrindai, nulemiantys jau suaugusio asmens sveikatą bei gyvenimo kokybę. Deja, būtent vaikystès ir paauglystes laikotarpiu, kuomet žmogaus organizmas yra itin jautrus, galimas ịvairių rizikos veiksnių poveikis. [1, 2]. Vienas iš svarbiausių veiksnių - sveikatai nepalanki mityba, kuri gali būti vaiko antsvorio, nutukimo ir įvairių ligų priežastimi [3]. Racionali, sveikos mitybos rekomendacijas atitinkanti mityba yra vienas iš pagrindinių sveiką augimą ir kai kurių ligų prevenciją lemiančių veiksnių [3, 4]. Pasak įvairių sričių specialistų, labai svarbu pradèti formuoti ir ugdyti sveikos gyvensenos ịpročius nuo ankstyvos vaikystès, nes būtent tada susiformavę ịpročiai gali išlikti visam gyvenimui [5].

Maži vaikai yra viena jautriausių grupių, kuriai mityba daro didžiausią įtaką [4]. Kol vaikas nelanko darželio ar mokyklos, šeima atlieka svarbiausią vaidmenį formuodama mitybos ịpročius. Vaikui pradejjus lankyti darželị ar mokyklą, jo mityba pradeda priklausyti ir nuo ugdymo įstaigos [6]. Nustatyta, kad vaiko harmoningą augimą, fizinị ir protinį brendimą lemia racionali mityba ir sveikos mitybos ipročių susiformavimas. Suaugęs asmuo laikysis tokių mitybos ịpročių, kokie jam buvo išugdyti vaikystèje, todèl siekiant geresnès ateities kartų sveikatos, būtina išskirtinị dèmèsị skirti tinkamų vaikų mitybos ịpročių formavimui [7].

Lietuvoje yra atlikta gana daug tyrimų, nagrinėjančių vaikų mitybos ypatumus, tačiau dažniausiai šiuose tyrimuose skiriamas dèmesys aukštesnèse klasėse besimokantiems mokiniams, kurių mitybos įpročius pakeisti sunku [7]. Dažnai pamirštami pradinių klasių mokiniai, kurie dèl to, kad jų ịpročiai dar nèra pilnai susiformavę, kaip tik turètų būti tyrèjų dèmesio centre. Taip pat svarbu paminèti, kad dauguma mūsų šalyje atliekamų tyrimų, kuriuose analizuojami vaikų mitybos ypatumai, priklauso momentiniams paplitimo tyrimams, o tyrimų, kurių metu būtų vertinamas pokytis toje pačioje pradinių klasių mokinių populiacijoje, Lietuvoje beveik nèra. Verta atkreipti dèmesį, kad iki šiol Lietuvoje buvo atliktas tik vienas pradinių klasių (pirmokų) mokinių mitybos ir fizinio aktyvumo pokyčių tyrimas Marijampolès apskrityje. Taigi mūsų tyrimas išskirtinis tuo, kad jo metu buvo nagrinejjami pradinių klasių mokinių mitybos pokyčiai.

Nuomonè ir žinios visuomenèje apie sveikatai palankius produktus ir mitybą dèl komercinès žiniasklaidos ne visada patikimais moksliniais tyrimais pagrịstos skleidžiamos informacijos bei dẻl vykdomų ịvairių sveikatos stipri- 
nimo programų nuolat keičiasi. Tẻvų ir ką tik pradėjusių lankyti mokyklą vaikų nuomonè ir žinios taip pat nuolat keičiasi kartu potencialiai pakeisdamos mitybos įpročius, todèl, norint išaiškinti tiek žiniasklaidos, ịvairių vykdomų programų daromą ịtaką ir sužinoti, ar judama teisinga linkme geresnès žmonių mitybos ir sveikatos link, svarbu ịvertinti pradinių klasių mokinių mitybos pokyčius. Būtent šio amžiaus vaikų mitybos pokyčių įvertinimo svarba ir lèmè mūsų tyrimo tikslą.

Tyrimo tikslas - nustatyti dviejų Vilniaus pradinių mokyklų mokinių mitybos pokyčių ypatumus.

\section{Tyrimo medžiaga ir metodai}

2010 metais Vilniaus universiteto Medicinos fakulteto Visuomenès sveikatos instituto mokslininkai vykdè Vilniaus miesto pradinių klasių mokinių mitybos ir gyvensenos ypatumų tyrimą, kuriame buvo atrinktos dvi Vilniaus miesto mokyklos, kuriose mokèsi pradinių klasių mokiniai. 2014 metų spalio - lapkričio mėnesiais, praejus 4 metams po pirmojo tyrimo, siekiant ịvertinti Vilniaus miesto pradi-

1 lentelè. Respondentų, teigiančių, kad jų šeimose laikomasi sveikos mitybos rekomendacijų, pasiskirstymas 2010 ir 2014 metais

\begin{tabular}{|l|c|c|c|}
\hline \multirow{2}{*}{ Metai } & \multicolumn{3}{|c|}{$\begin{array}{c}\text { Besilaikantys sveikos mitybos reko- } \\
\text { mendaciju }\end{array}$} \\
\cline { 2 - 4 } & $\mathrm{n}$ & $\%$ & $95 \%$ P.I. \\
\hline $\mathbf{2 0 1 0}$ m. $(\mathrm{n}=450)$ & 330 & $\mathbf{7 3 , 3}$ & 69,$1 ; 77,2$ \\
\hline $\mathbf{2 0 1 4}$ m. $(\mathrm{n}=342)$ & 290 & $\mathbf{8 4 , 8}$ & 80,$6 ; 88,2$ \\
\hline$\chi^{2}=15,016, \mathrm{p}=0,0001$ \\
\hline
\end{tabular}

2 lentelè. Respondentų vaikų pasiskirstymas pagal valgymų per dieną skaičių 2010 ir 2014 metais

\begin{tabular}{|l|l|l|l|l|l|l|}
\hline \multirow{2}{*}{ Metai } & \multicolumn{6}{|l|}{ Valgymų skaičius per dieną } \\
\cline { 2 - 7 } & $\leq 3$ k./d. & \multicolumn{3}{l|}{$\geq 4$ k./d. } \\
\cline { 2 - 7 } & $\mathrm{n}$ & $\%$ & $95 \%$ P.I. & $\mathrm{n}$ & $\%$ & $95 \%$ P.I. \\
\hline $\begin{array}{l}\mathbf{2 0 1 0} \mathbf{~ m .} \\
(\mathrm{n}=452)\end{array}$ & 151 & $\mathbf{3 3 , 4}$ & 29,$2 ; 37,9$ & 301 & $\mathbf{6 6 , 6}$ & 62,$1 ; 70,8$ \\
\hline $\begin{array}{l}\mathbf{2 0 1 4} \mathbf{~ m} . \\
(\mathrm{n}=337)\end{array}$ & 103 & $\mathbf{3 0 , 6}$ & 25,$9 ; 35,7$ & 234 & $\mathbf{6 9 , 4}$ & 64,$3 ; 74,1$ \\
\hline \multicolumn{7}{|l|}{$\chi^{2}=0,715, \mathrm{p}=0,398$} \\
\hline
\end{tabular}

3 lentelė. Respondentų vaikų pasiskirstymas pagal pusryčiavimą prieš einant ị mokyklą 2010 ir 2014 metais

\begin{tabular}{|c|c|c|c|c|c|c|c|c|c|}
\hline \multirow{3}{*}{ Metai } & \multicolumn{9}{|c|}{ Pusryčiavimas } \\
\hline & \multicolumn{3}{|c|}{ Taip } & \multicolumn{3}{|c|}{ Kartais } & \multicolumn{3}{|c|}{$\mathrm{Ne}$} \\
\hline & $\mathrm{n}$ & $\%$ & $95 \%$ P.I. & $\mathrm{n}$ & $\%$ & $95 \%$ P.I. & $\mathrm{n}$ & $\%$ & $95 \%$ P.I. \\
\hline $\begin{array}{l}\mathbf{2 0 1 0} \mathbf{~ m .} \\
(\mathrm{n}=458)\end{array}$ & 301 & 65,7 & 61,$3 ; 69,9$ & 92 & 20,1 & 16,$7 ; 24,0$ & 65 & 14,2 & 11,$3 ; 17,7$ \\
\hline $\begin{array}{l}\mathbf{2 0 1 4} \mathbf{~ m .} \\
(\mathrm{n}=346)\end{array}$ & 255 & 73,7 & 68,$8 ; 78,0$ & 54 & 15,6 & 12,$2 ; 19,8$ & 34 & 10,7 & 7,$9 ; 14,4$ \\
\hline
\end{tabular}

4 lentelė. Respondentų, teigiančių, kad jų vaikai užkandžiauja tarp pagrindinių valgymų, pasiskirstymas 2010 ir 2014 metais

\begin{tabular}{|l|c|c|c|}
\hline \multirow{2}{*}{ Metai } & \multicolumn{3}{|c|}{$\begin{array}{c}\text { Respondentai, kurių vaikai užkan- } \\
\text { džiauja }\end{array}$} \\
\cline { 2 - 4 } & $\mathrm{n}$ & $\%$ & $95 \%$ P.I. \\
\hline $\mathbf{2 0 1 0}$ m. $(\mathrm{n}=455)$ & 386 & $\mathbf{8 4 , 8}$ & 81,$3 ; 87,8$ \\
\hline $\mathbf{2 0 1 4}$ m. $(\mathrm{n}=338)$ & 281 & $\mathbf{8 3 , 1}$ & 78,$8 ; 86,8$ \\
\hline$\chi^{2}=0,419, \mathrm{p}=0,517$ & \multicolumn{4}{|l}{} \\
\hline
\end{tabular}

5 lentelė. Respondentų, teigiančių, kad jų vaikai valgo prieš miegą, pasiskirstymas 2010 ir 2014 metais

\begin{tabular}{|l|c|c|c|}
\hline \multirow{2}{*}{ Metai } & \multicolumn{3}{|c|}{ Respondentai, kurių vaikai valgo prieš } \\
& \multicolumn{3}{|c|}{ miegą } \\
\cline { 2 - 4 } & $\mathrm{n}$ & $\%$ & $95 \%$ P.I. \\
\hline $\mathbf{2 0 1 0}$ m. $(\mathrm{n}=455)$ & 251 & $\mathbf{5 5 , 2}$ & 50,$6 ; 59,7$ \\
\hline $\mathbf{2 0 1 4}$ m. $(\mathrm{n}=330)$ & 155 & $\mathbf{4 5 , 7}$ & 40,$5 ; 51,0$ \\
\hline$\chi^{2}=6,931, \mathrm{p}=0,008$ \\
\hline
\end{tabular}

nių klasių mokinių mitybos pokyčius, tose pačiose mokyklose buvo atliktas pakartotinis tyrimas. Abu momentiniai tyrimai buvo atlikti anoniminès anketinès apklausos būdu apklausiant kiekvieno pradinuko vieną iš tèvų. 2010 metais anketos buvo išdalintos visiems mokyklose besimokiusiems mokiniams. Iš 575 anketų buvo grąžinta 460 anketų (atsako dažnis 80\%). 2014 metais iš 526 išdalintų anketų buvo grąžinta 370 anketų (atsako dažnis 65,78\%).

Statistinei duomenų analizei buvo naudota SPSS Statistics 22.0 programa. Kokybinių kintamujjų analizei buvo naudotas Pearson'o chi kvadratas $\left(\chi^{2}\right)$, o kai buvo mažiau nei 5 tikètini dažniai - Fišerio tikslusis testas. Su WinPepi 11.39 programa buvo apskaičiuoti paplitimo rodiklių $95 \%$ pasikliautiniai intervalai (95\% P.I.). Duomenų skirtumas laikytas statistiškai reikšmingu, kai $\mathrm{p} \leq 0,05$.

2010 ir 2014 metais berniukų ir mergaičių skaičius buvo panašus (atitinkamai berniukų 45,7\% ir 47,7\%, mergaičių $54,3 \%$ ir 52,3\%). 2010 metais daugiausia mokinių mokèsi trečioje $(29,3 \%)$ bei ketvirtoje $(28,3 \%$, ) klasėje, o 2014 metais apklaustų tėvų vaikų daugiausia buvo pirmokų bei trečiokų (atitinkamai 30,6\% ir 25,4\%).

\section{Rezultatai}

Nustatyta, kad statistiškai reikšmingai 2014 metais nei 2010 metais buvo daugiau tėvų, kurie teigè, kad jų šeimoje laikomasi sveikatos mitybos rekomendacijų ( $84,8 \%$ ir $73,3 \%$ atitinkamai) (1 lentelè).

2010 metais 66,6\% apklaustų tèvų teigè, kad jų vaikai valgo 4 ir daugiau 
6 lentelè. Respondentų vaikų ịvairių maisto produktų grupių vartojimo ypatumai 2010 ir 2014 metais

\begin{tabular}{|c|c|c|c|c|c|c|}
\hline \multirow{3}{*}{ Metai } & \multicolumn{6}{|c|}{ Daržovių valgymų skaičius per dieną } \\
\hline & \multicolumn{3}{|c|}{$2 \mathrm{k} . / \mathrm{d}$. ir rečiau } & \multicolumn{3}{|c|}{$3 \mathrm{k} . / \mathrm{d}$. ir daugiau } \\
\hline & $\mathrm{n}$ & $\%$ & $95 \%$ P.I. & $\mathrm{n}$ & $\%$ & $95 \%$ P.I. \\
\hline 2010 m. $(\mathrm{n}=460)$ & 404 & 87,8 & 84,$5 ; 90,5$ & 56 & 12,2 & 9,$5 ; 15,5$ \\
\hline 2014 m. $(n=345)$ & 304 & 88,1 & 84,$3 ; 91,1$ & 41 & 11,9 & 8,$9 ; 15,7$ \\
\hline \multicolumn{7}{|c|}{$\chi^{2}=0,016, p=0,901$} \\
\hline \multicolumn{7}{|c|}{ Vaisių valgymų skaičius per dieną } \\
\hline 2010 m. $(n=460)$ & 355 & 77,1 & $73,180,8$ & 105 & 22,9 & 19,$2 ; 26,9$ \\
\hline 2014 m. $(n=345)$ & 258 & 75,0 & 70,$2 ; 79,3$ & 86 & 25,0 & 20,$7 ; 29,8$ \\
\hline \multicolumn{7}{|c|}{$\chi^{2}=1,718, p=0,190$} \\
\hline Duon & os ir g & ūdini & produktų va & gymų & kaičiu & per dieną \\
\hline 2010 m. $(n=460)$ & 329 & 71,5 & 67,$2 ; 75,5$ & 131 & 28,5 & 24,$6 ; 32,8$ \\
\hline 2014 m. $(n=345)$ & 261 & 75,7 & $70,979,9$ & 84 & 24,3 & $20,129,1$ \\
\hline \multicolumn{7}{|c|}{$\chi^{2}=0,514, p=0,474$} \\
\hline \multicolumn{7}{|c|}{ Pieno produktų valgymų skaičius per dieną } \\
\hline 2010 m. $(n=460)$ & 346 & 75,3 & $71,178,9$ & 114 & 24,7 & $21,128,9$ \\
\hline 2014 m. $(n=345)$ & 258 & 74,8 & 69,$9 ; 79,1$ & 87 & 25,2 & $20,930,1$ \\
\hline \multicolumn{7}{|c|}{$\chi^{2}=0,020, p=0,888$} \\
\hline \multicolumn{7}{|c|}{ Mėsos, paukštienos, žuvies, kiaušinių valgymų skaičius per dieną } \\
\hline 2010 m. $(n=460)$ & 388 & 84,3 & $80,787,46$ & 72 & 15,7 & 12,$6 ; 19,3$ \\
\hline 2014 m. $(\mathrm{n}=345)$ & 302 & 87,2 & $83,490,46$ & 44 & 12,7 & $9,616,6$ \\
\hline$\chi^{2}=1,381, p=0,24$ & & & & & & \\
\hline
\end{tabular}

7 lentelè. Respondentų, teigiančių, kad jų vaikai vartoja maisto papildus, pasiskirstymas 2010 ir 2014 metais

\begin{tabular}{|l|c|c|c|}
\hline \multirow{2}{*}{ Metai } & \multicolumn{3}{|c|}{$\begin{array}{c}\text { Respondentai, kurių vaikai vartoja } \\
\text { maisto papildus }\end{array}$} \\
\cline { 2 - 4 } & $\mathrm{n}$ & $\%$ & $95 \%$ P.I. \\
\hline $\mathbf{2 0 1 0}$ m. $(\mathrm{n}=455)$ & 202 & $\mathbf{4 4 , 4}$ & 39,$9 ; 49,0$ \\
\hline $\mathbf{2 0 1 4}$ m. $(\mathrm{n}=342)$ & 180 & $\mathbf{5 2 , 6}$ & 47,$3 ; 57,9$ \\
\hline$\chi^{2}=5,307, \mathrm{p}=0,021$ \\
\hline
\end{tabular}

8 lentelẻ. Ekologiškų maisto produktų ịtraukimas ị vaiko mitybos racioną 2010 ir 2014 metais

\begin{tabular}{|c|c|c|c|c|c|c|c|c|c|}
\hline \multirow{3}{*}{ Metai } & \multicolumn{9}{|c|}{ Ekologiškų maisto produktų įtraukimas ị racioną } \\
\hline & \multicolumn{3}{|c|}{ Taip } & \multicolumn{3}{|c|}{ Kartais } & \multicolumn{3}{|c|}{$\mathrm{Ne}$} \\
\hline & $\mathrm{n}$ & $\%$ & $95 \%$ P.I. & $\mathrm{n}$ & $\%$ & $95 \%$ P.I. & $\mathrm{n}$ & $\%$ & $95 \%$ P.I. \\
\hline $\begin{array}{l}2010 \text { m. } \\
(n=454)\end{array}$ & 245 & 43,9 & 49,$4 ; 58,5$ & 192 & 42,3 & 37,$8 ; 46,8$ & 17 & 3,8 & 2,$4 ; 5,9$ \\
\hline $\begin{array}{l}\mathbf{2 0 1 4} \mathbf{~ m .} \\
(\mathrm{n}=344)\end{array}$ & 202 & 58,7 & 53,$5 ; 63,8$ & 121 & 35,2 & 30,$3 ; 40,4$ & 21 & 6,1 & 4,$0 ; 9,2$ \\
\hline
\end{tabular}

9 lentelè. Respondentų vaikų pasiskirstymas pagal išgeriamų skysčių kiekį per dieną 2010 ir 2014 metais

\begin{tabular}{|c|c|c|c|c|c|c|c|c|c|}
\hline \multirow{3}{*}{ Metai } & \multicolumn{9}{|c|}{ Išgertų skysčių kiekis } \\
\hline & \multicolumn{3}{|c|}{$0,5-1 \quad 1 . / \mathrm{d}$} & \multicolumn{3}{|c|}{$1-1,51 . / \mathrm{d}$. } & \multicolumn{3}{|c|}{$1,5-2$ 1./d. } \\
\hline & n & $\%$ & $95 \%$ P.I. & n & $\%$ & $95 \%$ P.I. & n & $\%$ & $95 \%$ P.I. \\
\hline $\begin{array}{l}2010 \text { m. } \\
(n=454)\end{array}$ & 217 & 47,8 & 43,$2 ; 52,4$ & 198 & 43,6 & 39,$1 ; 48,2$ & 39 & 8,9 & 6,$4 ; 11,5$ \\
\hline $\begin{array}{l}\mathbf{2 0 1 4} \mathbf{~ m} . \\
(\mathrm{n}=345)\end{array}$ & 172 & 49,9 & 44,$6 ; 55,1$ & 156 & 45,2 & 40,$1 ; 50,5$ & 17 & 4,9 & 3,$1 ; 7,8$ \\
\hline
\end{tabular}

kartų per dieną, 2014 metais taip teigusių tėvų dalis nežymiai padidèjo ir sudarè 69,4\% (2 lentelè).

2014 metais prieš mokyklą kasdien pusryčiaujančių vaikų $(73,7 \%)$ buvo reikšmingai daugiau nei kasdien pusryčiaujančių vaikų 2010 metais $(65,7 \%)$. Taip pat nustatyta, kad statistiškai reikšmingai 2014 metais buvo mažiau vaikų, kurie prieš einant ị mokyklą nepusryčiauja (10,7\% ir 14,23\% atitinkamai) (3 lentelè).

2010 metais tarp pagrindinių valgymų užkandžiavo 84,8\% respondentų vaikų, 2014 metais užkandžiaujančių vaikų dalis $83,1 \%$, tačiau šis skirtumas statistiškai reikšmingas nebuvo (4 lentelè).

$55,2 \%$ tèvų 2010 metais teigè, kad vaikai valgo prieš miegą, 2010 metais taip teigusių tèvų dalis statistškai reikšmingai sumažejo ir sudare $45,7 \%$ respondentų (5 lentelè).

Vertinant įvairių maisto produktų grupių, tokių kaip vaisiai, daržovès, pieno produktai, vartojimo ypatumus 2010 bei 2014 metais reikšmingų skirtumų nustatyta nebuvo (6 lentelè). Tyrimo duomenimis, 2010 metais 3 ir daugiau kartų per dieną daržoves valgydavo tik $12,2 \%$ respondentų vaikų, 2014 metais taip besimaitinančių vaikų dalis sumažèjo ir sudarè tik 11,9\%. Nustatyta, kad padaugèjo vaikų, 3 ir daugiau kartų per dieną valgančių vaisius (nuo 22,9\% 2010 metais iki 25,0\% 2014 metais), tačiau sumažèjo vaikų, kurie 3 ir daugiau kartų per dieną vartoja duoną ir grūdinius produktus (nuo 28,5\% 2010 metais iki 24,3\% 2014 metais). 2014 metais pieno produktus 2 kartus per dieną ir rečiau valgančių vaikų buvo mažiau nei 2010 metais (74,8\% ir 75,3\% atitinkamai). Mèsą, žuvị, paukštieną ir kitus baltyminius produktus 2010 metais 2 kartus per dieną ir rečiau valgè $84,3 \%$ respondentų vaikų, 2014 metais $-87,3 \%$.

2010 metais maisto papildus (vitaminus, mineralus ir pan.) vartojo $44,4 \%$ respondentų vaikų, o 2014 metais - 52,6\%. Šis nustatytas skirtumas buvo statistiškai reikšmingas (7 lentelè).

Vertinant ekologiškų maisto produktų itraukimą i mitybos racioną 2010 bei 2014 metais reikšmingų skirtumų nustatyta nebuvo, tačiau svarbu paminèti, kad per ketverius metus padaugèjo respondentų, i vaiko mitybos racioną itraukiančių ekologiškus produktus (2014 metais - 43,9\%, 2014 metais - 58,7\%), (8 lentelè).

Respondentų vaikai pagal išge- 
riamų skysčių kieki per dieną 2010 bei 2014 metais pasiskirste panašiai. 2010 metais 1,5-2 litrus per dieną skysčiu išgerdavo $8,9 \%$ vaikų, 1-1,5 litrus per dieną - 43,6 \%, 2014 metais atitinkamai $-4,9 \%$ ir 45,2 \%, tačiau šie skirtumai statistiškai reikšmingi nebuvo (9 lentelè).

\section{Rezultatų aptarimas}

Vaiko mityba priklauso nuo jo šeimos mitybos. Jei šeimos mityba bus nepalanki sveikatai, tuomet tai darys ittaką vaiko sveikatai [8]. 2013 metais Klaipedoje atlikto tyrimo duomenimis, 66,7 \% tèvų savo ikimokyklinio amžiaus atžalas sveikos mitybos ugdo patys, o 73,0 \% žinojo apie sveikos mitybos piramidę, ir iš jų $30 \%$ nurodè, kad vadovaujasi jos nurodymais, $55 \%$ - kartais [9]. 2014 metu Klaipedos 3-4 klasių mokinių mitybos tyrimo duomenimis, $53,8 \%$ su tèvais kartais kalbasi apie sveiką mitybą [9]. Mūsų atliktame tyrime 2014 metais 84,8 \% respondentų nurode, kad šeimoje laikosi sveikos mitybos rekomendacijų, 2010 metais $-73,3 \%$.

Vaikams rekomenduojama reguliariai per dieną valgyti 4 kartus ir daugiau kartu [10]. 2010 metais vykdyto Lietuvos didžiujų miestų pirmokų mitybos tyrimo duomenimis, 4 ir daugiau kartų per dieną valgé $69,1 \%$ pirmokų [9]. Marijampoleje 2013 metais atlikto 2008 ir 2013 metu pirmoku mitybos ipročių palyginamojo tyrimo duomenimis, 2008 metais 4 ir daugiau kartu per dieną valgydavo $81,4 \%$ pirmokų, 2013 metais - 67,3\% [11]. Atlikus mūsų tyrimą nustatyta, kad 2010 metais 4 ir daugiau kartų per dieną valgé $66,6 \%$ (70,7 \% pirmokų) respondentų vaikų, o 2014 metais $-69,4 \%$ (79,4 \% pirmokų).

2008 ir 2013 metais Marijampolejje vykdyto pirmokų mitybos tyrimo duomenimis, 2008 metais pusryčius kasdien valgydavo 65,0\% pirmokų, 2013 metais - 58,2\%, atitinkamai niekada nevalgydavo pusryčių 10,2\% ir 8,7\% vaikų [11]. 2014 metais Klaipédoje vykdyto 3-4 klasių mokinių mitybos tyrime $62,7 \%$ mokinių nurode, kad visuomet valgo pusryčius, o 4,7\% teigè niekada nevalgantys pusryčių [9]. Mūsų atlikto tyrimo duomenimis, 2010 metais pusryčius kasdien valgydavo $65,7 \%$ pradinių klasių mokinių, 2014 metais $-73,7 \%$ vaikų.

2014 metų Klaipeddoje vykdyto 3-4 klasių mokinių mitybos tyrimo duomenimis, $25,4 \%$ respondentų nurodè, kad visada perka ekologiškus maisto produktus, 9,8\% apklaustụjų teigè niekada tokių produktų neperka [9]. Mūsų atlikto tyrimo duomenimis, 2010 metais ekologiškų maisto produktų i vaiko mitybos racioną ịtraukdavo $43,9 \%$ tèvų, niekada neittraukdavo $-3,8 \%$, (2014 metais atitinkamai 58,7\% ir $6,1 \%)$.

JAV atlikto tyrimo duomenimis, 4-8 metų vaikai per dieną išgeria 0,35 litro vandens, 9-13 metų $-0,5$ litro [12].
Mūsų tyrimo duomenimis, daugiausia vaikų išgeria 0,5-1 litro skysčių per dieną (2010 metais - 47,8\%, 2014 metais $-49,9 \%)$.

\section{Išvados}

1. Padaugejjo tèvų, teigiančių, kad jų šeimose laikomasi sveikos mitybos rekomendacijų, bei sumažèjo tèvų, teigiančių, kad jų atžalos valgo prieš miegą.

2. Padaugèjo prieš mokyklą kasdien pusryčiaujančių vaiku, taip pat pradinukų, kurie vartoja maisto papildus.

3. Nepasikeitè dalis vaikų, valgančių 4 ir daugiau kartų per dieną, užkandžiaujančių tarp pagrindinių valgymų bei vartojančių mažiau nei rekomenduojama daržovių, vaisių ir grūdinių produktų.

4. Ekologiškų maisto produktų ịtraukimas į mitybos racioną bei vaikų išgeriamų skysčių kiekis išliko panašus.

\section{Literatūra}

1. Dailidienè N., Juškelienė V., Naudžiūtè S. Lietuvos vaikų, lankančiu ikimokyklinio ugdymo įstaigas, sveikatos būklè. Visuomenès sveikata, 2009; 3: 3-8.

2. Sabaliauskas R. Saugi ir sveika aplinka vaikams. Slauga, 2004; 9(93): 3-5.

3. Stukas R., Šurkienė G. Mityba ir jos vertinimas. Vilnius. Vilniaus universiteto leidykla, 2009.

4. Licari L. et al. Children"s health and environment. Developing action plans. WHO 2005; 88.

5. Strukčinskienė B., Raistenskis J., Šopagienė D., Kurlys D., Stasiuvienè D., Griškonis S., Radžiuvienè R. Vaikų fizinis aktyvumas ir sveikata. Klaipèda. S. Jokužio leidykla-spaustuvė, 2012.

6. Dixey R, Heindl I, Loureiro I, Pérez-Rodrigo C, Snel J, Warnking P. Healthy eating for young people in Europe. A schoolbased nutrition education guide, 1999.

7. Petrauskienė A., Albavičiūtè E., Žaltauskè V., Navardauskaitė T. Penkių didžiujų Lietuvos miestų pirmokų mitybos ịpročiai. Visuomenès sveikata, 2012; 4(59):103-111.

8. Montvilienè I., Žuravliova T., Norkienė S., Mažrimas A. Ikimokyklinio amžiaus vaikų mityba tėvų požiūriu. Sveikatos mokslai, 2014; 4:44-47.

https://doi.org/10.5200/sm-hs.2014.067

9. Strukčinskienė B., Strazdienė N., Griškonis S. Pradinių klasių mokinių mitybos namuose ir mokykloje ypatumai. Sveikatos mokslai, 2015; 4:5-9.

https://doi.org/10.5200/sm-hs.2015.063

10. Sveikatos mokymo ir ligų prevencijos centras, Vilniaus universiteto Medicinos fakultetas, Kauno medicinos universitetas. Sveikos mitybos rekomendacijos" Vilnius, 2010; 22.

11. Petrauskienẻ A., Rugytė A., Albavičiūtè E. Marijampolès apskrities pirmokų mitybos ir fizinio išsivystymo ypatumai ir pokyčiai per penkerius metus. Visuomenès sveikata, 2014; 2(65):87-96. 
12. Adam Drewnowski et al. Water and beverage consumption among children age 4-13y in the United States: analyses of 2005-2010 NHANES data. Nutrition Journal. 2013; 12(1):1-9. https://doi.org/10.1186/1475-2891-12-85

\section{CHANGES OF NUTRITIONAL HABITS OF PRIMARY SCHOOLCHILDREN. COMPARATIVE STUDY OF YEAR 2010 AND 2014 \\ Ž. Žandaras, R. Stukas}

Key words: pupils of primary school, diet, changes in diet.

Summary

The aim of the study to compare eating habits of pupils of primary schools in two schools in Vilnius city in a time period between 2010 and 2014 .

Material and methods: In 2010 in two primary schools in Vilnius city 460 parents of pupils' forms 1-4 were questioned in a technique of anonymous survey. In 2014346 parents were questioned by analogy. Data were analyzed using program SPSS 22.0.
For qualitative data analysis Pearson's chi-square $\left(\mathrm{x}^{2}\right)$ was used. The difference was considered statistically significant when $p<0,05$.

Results: In 2010 73,3\% parents of pupils of primary schools followed a healthy dietary recommendations, in 2014 the percentage increased to $84,8 \%$, respectively $65,7 \%$ and $73,7 \%$ had breakfast every day, 55,2 \% and 45,7\% ate before going to sleep. In 2010 12,2 $\%$ of children respondents ate vegetables 3 and more times a day, in $2014-11,9 \%$, in line with fruit $22,9 \%$ and $25,0 \%$, bread and cereal $-28,5 \%$ and $24,3 \%$. In $201044,4 \%$ of pupils of primary schools consumed food supplements, in $2014-52,6 \%$.

Conclusions: The numbers increased of parents who follow a healty dietary recommendations and of primary school pupils who have breakfast, consume food supplements.

Correspondence to: zymantas.zandaras@gmail.com

Gauta 2017-01-09 